\author{
А. Т. Хроленко \\ Курский государственный университет \\ Курск, Россия \\ alexanderhrolenko@yandex.ru
}

\title{
Сопоставительный анализ конкордансов курских и кубанских народных песен как средство выявления дифференцирующих признаков фольклорных диалектов
}

В становлении фольклорной диалектологии свое место занимает формирование комплекса языковых признаков для территориальной идентификации народно-поэтических текстов.

Наше лексикографическое описание фольклорного материала разных жанров дает основание полагать, что сопоставление конкордансов, представляющих большие массивы, может способствовать выявлению и систематизации территориальных признаков фольклорных текстов.

Реальный опыт поиска покажем на примере трех конкордансов, составленных курскими лингвофольклористами: 1) курские народные необрядовые лирические песни, включенные в свод А. И. Соболевского «Великорусские народные песни» (т. 2-6) [Бобунова, Хроленко, 2007]; 2) балладные, юмористические и сатирические песни Курской губернии из свода А. И. Соболевского (т. 1 и 7) [Бобунова, 2019]; 3) русскоязычные песни казаков Кубани, собранные А. Д. Бигдаем и Г. М. Концевичем [Литус, 2007].

В поисках устойчивых территориальных признаков песенного текста возможны два пути - сюжетный и лингвофольклористический. Сюжетный подход учитывает содержание песни и очевидные знаки места событий песни. Это северокавказская топонимия (Анапа, Арпачай, Дагестан, Белая-река), антропонимия - имена реальных персон, связанных с историей Кавказа и Кубани (Атажупов, Бакланов, Барятинский, Баур), экзотизмы (абрек, арчак, аскер, аул, делибаи), названия оружия и воинской амуниции (артиллерия, батарея, берданка, винтовка, бурка).

Лингвофольклористический подход учитывает лексическую семантику и особенности связи слов (например, эпитетосочетания). (C) Хроленко А. Т., 2019 
Так, признаками территориальной отнесенности того или иного текста могут служить диалектизмы. Местные слова выглядаться, вербажи, гаметь, горкать диалектологи квалифицируют как исключительно курские лексемы. В кубанских песнях местными являются слова правдица, подабычиться, бело-зоновый. К тому же в песнях Кубани наличествуют слова, которые В. И. Даль в своем словаре снабдил пометой «юж.», а другие диалектологи - «малорос.» (гай, гаманеи, горелка, важкий, выхиляться, зозуля, корчма, коханьий, ожинушка).

Методику и результат лингвофольклористического анализа покажем на примере сопоставления словарных статей «Зеленый» из трех конкордансов. В курских песнях зеленый - 91 с/у, количество определяемых объектов (и соответственно, существительных) - 24; в кубанских - 64 с/у и 17 объектов (существительных). Прежде всего выявляются общие для курских и кубанских песен эпитетосочетания типа зеленый сад, зеленое вино, зеленая груша, зеленая сосна, зеленый луг, которые обозначают устойчивые элементы общерусской фольклорноязыковой картины мира. Есть и сравнительно частые эпитетосочетания, используемые только в одной песенной традиции. Для курской песни это зеленая мурава и зеленый кафтан, для кубанской - зеленая рассада. Можно считать, что тексты с зеленой муравой и зеленой рассадой принадлежат разным фольклорным диалектам.

Обратимся к существительному кафтан с точки зрения цветовой характеристики.

Курск: «У зеленом кафтане, / Рубашка тонкая»; «На детинушке зелен кафтан...»; «Через тихий Дон поплыть, — / Зелен кафтан намочить...»; «Он во зеленом кафтане...»; «Зелен кафтан моего друга на столе лежит...»; «Зелен кафтан изодрал, по заборам лазючи...» [Бобунова, Хроленко, 2007, 88]; «Серая овечка / Барана окотила, / В зеленом кафтане / Шляпа пуховая» [Бобунова, 2019, 227].

Кубань: «... В кафтан себя одевали»; «Они кафтан одевали...» [Литус, 2007, 114].

Единичность и «бесцветность» на фоне иных «цветовых» решений тоже может быть территориальным признаком.

Кстати, заметим: ранее куряне установили, что если в курских песнях кафтан только зеленый, то в северных (архангельских и олонецких) песнях кафтан исключительно голубого или синего цвета. Почему? На этот счет у нас ответа пока нет, но обратим внимание на смысловые 
различия цвета кафтана, на которые намекают две пословицы из словаря В. И. Даля: Кафтан зеле́н, да бит ежедён; Пуст карман, да синь кафтан (Даль к этой пословице оставил комментарий: «щеголь»). Зелен кафтан - знак социального статуса, а синь кафтан - общественного престижа?

Поиск неожиданных и в то же время устойчивых примет фольклорных диалектов, свидетельствующих о месте становления и/или бытования народно-поэтического текста, — одна из увлекательных задач фольклорной диалектологии, в арсенале которой наличествует фольклорная лексикография.

Бобунова М. А. Балладные песни Курской губернии. Конкорданс // Бобунова М. А. Лексикографический комплекс фольклорных текстов: Песни Курской губернии. Курск, 2019. С. 49-156.

Бобунова М. А., Хроленко А. Т. Конкорданс русской народной песни. Т. 1 : Песни Курской губернии. Курск, 2007.

Литус Е. В. Фольклорное слово Кубани: Конкорданс народных песен линейных казаков Кубани. Курск, 2007.

DOI 10.31168/7996-2700-3.129

\section{А. В. Черных}

Пермский федеральный исследовательский центр УрО РАН

Пермь, Россия

atschernych@yandex.ru

\section{Названия старообрядцев \\ в диалектной речи русского населения Пермского края*}

Наличие значительного числа старообрядцев в Прикамье, их конфессиональное противопоставление сторонникам официальной православной церкви обусловили бытование целого ряда номинаций,

\footnotetext{
* Исследование выполнено в рамках реализации проекта № 18-6-6-4 «Межэтнические отношения в Прикамье: исторический опыт и современные практики» комплексной программы фундаментальных исследований УрО РАН.

(C) Черных А. В., 2019
} 